\title{
Contribution to atmospheric benzene concentrations of the petrol stations in a mid-sized city
}

\author{
L. T. Silva, J. F. G. Mendes \& C. M. Silva \\ Department of Civil Engineering, University of Minho, Portugal
}

\begin{abstract}
In an urban environment the typical anthropogenic sources of benzene are mainly the road traffic. Other important sources are petrol stations and smallscale industries using benzene as a solvent, such as the printing industry, etc. Petrol stations are the most significant of these additional sources. Evaporative emissions from petrol station operations include contributions due to the filling underground tank operations, due to the underground tank breathing and emptying, due to vehicle refuelling operations and lastly due to spillage. The petrol stations are frequently located in populated urban areas consequently exposing the population to this kind of pollution. The present study assesses the contribution of petrol stations to the ambient benzene concentrations in a midsized city. The scientific toolbox adopted to develop the studies includes an air quality simulation model and a GIS platform. Based on the method and the rate of filling, tank configuration and gasoline properties the evaporative emissions from petrol stations are calculated. This paper aims at presenting the approach, including the theoretical framework, and at discussing the results and their role within the city's quality of life argument.
\end{abstract}

Keywords: urban air pollution, air pollution modelling, benzene.

\section{Introduction}

Urban air pollution has become one of the main contributors to the degradation of the quality of life in cities. This problem tends to worsen due to the unbalanced development of urban spaces and the significant increase in mobility and road traffic. As a consequence, total emissions from road traffic have risen 
significantly, assuming the main responsibility for the disregard of air quality standard [1].

Atmospheric pollutants are emitted from existent sources and, subsequently, transported, dispersed and transported several times in the atmosphere reaching several receivers through wet deposition (through rainout and washout of the rain and snow) or dry deposition (through the adsorption of particles). In urban environments the typical anthropogenic sources are mainly the road traffic and, when existing, industrial activity.

The compounds from the exhaustion gases of the road vehicles released to the atmosphere create impacts on different geographical scales and time [2]. Certain compounds possess an immediate and located effect. For instance, a plume of black smoke is instantly unpleasant for people observing it, while in a long run scale repeated exposures to the black smoke of the exhaust of vehicles can cause, through deposition of particles on the surface of the buildings, the darkening of their facades.

The combustion of hydrocarbon fuel in the air generates mainly carbon dioxide $\left(\mathrm{CO}_{2}\right)$ and water $\left(\mathrm{H}_{2} \mathrm{O}\right)$. However, the combustion engines are not totally efficient, which means that the fuel is not totally burnt. In this process the product of the combustion is more complex and can be constituted by hydrocarbons and other organic compounds as well as benzene $\left(\mathrm{C}_{6} \mathrm{H}_{6}\right)$, carbon monoxide (CO) and particles (PM) that contain carbon and other pollutants. On the other hand, the combustion conditions - high pressures and temperatures originate partial oxidation of the nitrogen present in the air and in the fuel, forming oxides of nitrogen (mainly nitric oxide and some nitrogen dioxides) conventionally designated by NOx. Among the hydrocarbons, benzene is the compound with the greatest environmental impact.

Many of the atmospheric pollutants once emitted from the road vehicles react with the components of the air or react together and form the so-called secondary pollutant [3]. Due to the dispersion effect happened during the reaction, the concentration of the secondary pollutants doesn't usually reach maximum values near to the emission source. The impact can however extend to great areas not confined to the area of the road traffic.

It is estimated that the main source of benzene in urban areas is traffic. Additional sources are petrol stations, dry cleaners, and small-scale industries Petrol stations are the most significant from these additional sources [4].

Benzene is a very dangerous pollutant for the public health due to its toxicity and its carcinogenicity [5]. Benzene is rapidly but incompletely absorbed by humans and it is classified by the International Association on the Risks of Cancer as a Class 1 carcinogen [6].

Benzene is a naturally occurring colourless liquid at room temperature $\left(25^{\circ} \mathrm{C}\right)$ and pressure $(760 \mathrm{~mm} \mathrm{Hg})$. It has a characteristic aromatic odour, a relatively low boiling point $\left(80.1^{\circ} \mathrm{C}\right)$ and high vapour pressure, which causes it to evaporate rapidly at room temperature. Benzene is a volatile organic compound with a very stable ring-shaped chemical structure that constitutes the base of the aromatic hydrocarbon family. It is a natural component of crude oil and it is consequently found in certain refined products, such as gasoline [4]. Benzene is 
quite stable in the atmosphere, the residence time varying between few hours to a few days depending on the environment and meteorological conditions. Benzene is released into the environment from both natural and anthropogenic source, although the latest is the most significant source.

As lead-containing antiknock additives were reduced and eliminated, throughout the past 15 years more aromatics (including benzene) have been blended into gasoline for antiknock purposes and, consequently, benzene concentrations have increased to more than 5\% [7,8].

In line with most of the EU countries, Portuguese specific legislation requires local government authorities to manage air quality in their areas, with the aim of achieving the objectives laid out in table 1 .

Table 1: $\quad$ Portuguese annual limit values for the protection of human health $[9,10]$.

\begin{tabular}{|l|l|l|}
\hline Pollutant & Averaging period & Value \\
\hline Benzene $\left(\mathrm{C}_{6} \mathrm{H}_{6}\right)$ & Calendar year & $5 \mu \mathrm{g} / \mathrm{m}^{3}$ \\
\hline Nitrogen dioxide $\left(\mathrm{NO}_{2}\right)$ & Calendar year & $40 \mu \mathrm{g} / \mathrm{m}^{3}$ \\
\hline Ozone $\left(\mathrm{O}_{3}\right)$ & 8 hours (rolling average) & $110 \mu \mathrm{g} / \mathrm{m}^{3}$ \\
\hline Particulate matter $\left(\mathrm{PM}_{10}\right)$ & Calendar year & $40 \mu \mathrm{g} / \mathrm{m}^{3}$ \\
\hline
\end{tabular}

The aim of this paper is to evaluate the contribution of petrol stations to the ambient benzene concentrations in a mid-sized Portuguese city - Viana do Castelo. Based on the method and the rate of filling, tank configuration and gasoline properties the evaporative emissions from gasoline service stations are calculated.

\section{Evaporative emissions from petrol stations operations}

Evaporative emissions from petrol stations may be classified into three categories:

a) by loading losses

b) by underground tank breading losses

c) by refuelling losses

Loading losses are the primary source of evaporative emissions. Loading losses occur as organic vapours in "empty" cargo tanks are sent to the atmosphere by liquid being loaded into the tanks. These vapours are a combination of vapours formed in the empty tank by evaporation of residual product from previous loads, vapours transferred to the tank in vapour balance systems as the product is being unloaded, and vapours generated in the tank as the new product is being loaded.

The amount of evaporative losses of loading operations is, subsequently, a function of the following parameters [11]:

a) Physical and chemical characteristics of the last cargo;

b) Method of unloading the last cargo;

c) Operations to transport the empty carrier to a loading terminal; 


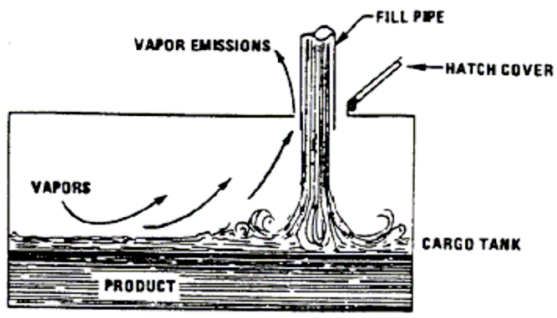

a) Splash loading method

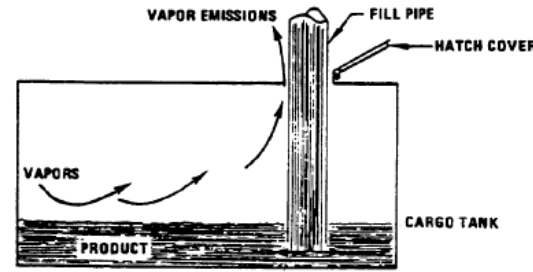

b) Submerged fill pipe

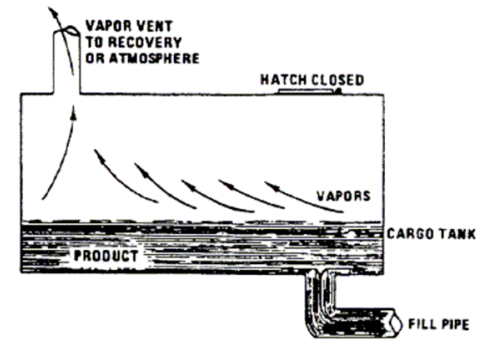

c) Bottom loading

Figure 1: $\quad$ Loading losses [11].

d) Method of loading the new cargo;

e) Physical and chemical characteristics of the new cargo.

The principal methods of filling the underground gasoline storage tanks at service stations are illustrated in Fig. 1.

In the splash loading method, the fill pipe opening is above the liquid surface level. Significant turbulence and vapour/liquid contact happen during the splash loading operation, resulting in high levels of vapour generation and loss.

The submerged loading can be done by two processes: submerged fill pipe and bottom loading. In the submerged fill pipe method, the fill pipe extends almost to the bottom of the cargo tank. In the bottom loading method, a permanent fill pipe is attached to the cargo tank bottom. During most of the submerged loading by both methods, the fill pipe opening is below the liquid surface level. Liquid turbulence is controlled significantly during the submerged loading, resulting in much lower vapour generation than encountered during splash loading.

Emissions from loading petroleum liquid can be estimated by eqn. (1):

$$
L_{L}=12.46 \frac{S P M}{T}
$$

where:

$L_{L}$, loading loss $\left(\mathrm{lb} / 10^{3} \mathrm{gal}\right)$

$\mathrm{S}$, a saturation factor (see Table 2)

$\mathrm{P}$, true vapour pressure of liquid loaded per square inch absolute (psia)

$\mathrm{M}$, molecular weight of vapours (lb/lb-mole)

$\mathrm{T}$, temperature of bulk liquid loaded, ${ }^{\circ} \mathrm{R}$. 
The saturation factor, S, represents the expelled vapour's fractional approach to saturation, and it accounts for the variations observed in emission rates from the different unloading and loading methods. Table 2 lists the saturation factors.

Table 2: $\quad$ Saturation factors for calculating loading losses [11].

\begin{tabular}{|l|l|}
\hline Mode of operation & S Factor \\
\hline Submerged loading of a clean cargo tank & 0.50 \\
\hline Submerged loading, dedicated ${ }^{1}$ normal service & 0.60 \\
\hline Submerged loading, dedicated ${ }^{1}$ vapour balance service & 1.00 \\
\hline Splash loading of a clean cargo tank & 1.45 \\
\hline Splash loading, dedicated ${ }^{1}$ normal service & 1.45 \\
\hline Splash loading, dedicated ${ }^{1}$ vapour balance service & 1.00 \\
\hline
\end{tabular}

${ }^{1}$ Cargo carries designated to transport only one product.

At the service stations the major source of evaporative emissions is the filling of underground gasoline storage tanks. Emissions are generated when vapours in the underground storage tank are displaced to the atmosphere by the gasoline being loaded into the tank.

The amount of loss in service station tank filling depends on several variables:

a) method and rate of filling

b) tank configuration

c) gasoline temperature

d) vapour pressure and composition

Table 3 lists the average emission rate from gasoline service station operations.

Table 3: Evaporative emissions from gasoline service station operations ${ }^{1}$ [11].

\begin{tabular}{|l|c|}
\hline Emission source & $\begin{array}{l}\text { Emission Rate } \\
\mathrm{mg} / \mathrm{L} \text { throughput }\end{array}$ \\
\hline Loading Loss & 880 \\
\hline Submerged filling of the underground tank & 1380 \\
\hline Splash filing of the underground tank & 40 \\
\hline $\begin{array}{l}\text { Balanced submerged filing of the underground } \\
\text { tank }\end{array}$ \\
\hline Underground Tank Breading Losses \\
\hline Underground tank breading and emptying & 120 \\
\hline Refuelling Losses & 1320 \\
\hline Uncontrolled displacement losses & 132 \\
\hline Controlled displacement losses & 80 \\
\hline Spillage
\end{tabular}

${ }^{1}$ Factors are VOC as well as total organic emissions, because of the methane and ethane content of gasoline evaporative emissions is negligible. 
The second source of vapour emissions from service stations is the underground tank breathing. The amount of displaced vapours depends on gasoline temperature, gasoline RVP, auto tank temperature and dispensing rate.

Service station vehicles refuelling operation also produces evaporative emissions which come from vapours displaced from the automobile tank by dispensed gasoline and from spillage. The latest is due to the pre-fill and post-fill nozzle drip and overflow from vehicles fuel tank during the filling. The quantity of spillage loss depends on tank configuration, operator techniques and service station business characteristics.

\section{Contribution to atmospheric benzene concentrations of the petrol stations in Viana do Castelo}

The study aimed at evaluating the impact of petrol stations on benzene concentration in the Portuguese city of Viana do Castelo, located in the northwest seaside. This is a mid-sized city, which has a population of 36.544 inhabitants living in an overall area of $37,04 \mathrm{Km}^{2}$.

Based on service stations data and physical characteristics of the area, it was created a horizontal map of benzene concentration. A range of numerical models was used to produce results. The computer model AUSTAL2000 [12] developed by German National Environmental Protection Agency was used for the pollutant dispersion and the AP42-USEPA methodology was used to estimate the evaporative emissions from gasoline service station operations.

\subsection{Calculation of evaporative emissions}

According to the DGEG (General Direction of Energy and Geology) [14] database, the city of Viana do Castelo possesses eight petrol stations. Fig. 2 shows the location of the eight petrol stations and Table 4 describes the fuel sold by each one.

The annual sales of fuel obtained from DGEG database is related to the municipal district. In order to determine the quantity of fuel sold in the city of Viana do Castelo it was taken into account the ratio population of the city/population of the municipal district. It was assumed that each petrol station sold the same amount of 95 octane and 98 octane gasoline and the results can be observed in the Table 5 .

Table 4: Petrol stations characteristics.

\begin{tabular}{|l|c|c|}
\hline Petrol station number & $\begin{array}{c}\text { Gasoline } \\
95 \text { octane }\end{array}$ & $\begin{array}{c}\text { Gasoline } \\
98 \text { octane }\end{array}$ \\
\hline Petrol 1,2 and 3 & Yes & No \\
\hline Petrol $4,5,6,7$ and 8 & Yes & Yes \\
\hline
\end{tabular}

In order to find the evaporative emissions from gasoline service stations operations it was used the USEPA AP42 methodology. Table 6 lists the emission factors of Volatile Organic Compounds (VOC) calculated for the petrol stations 


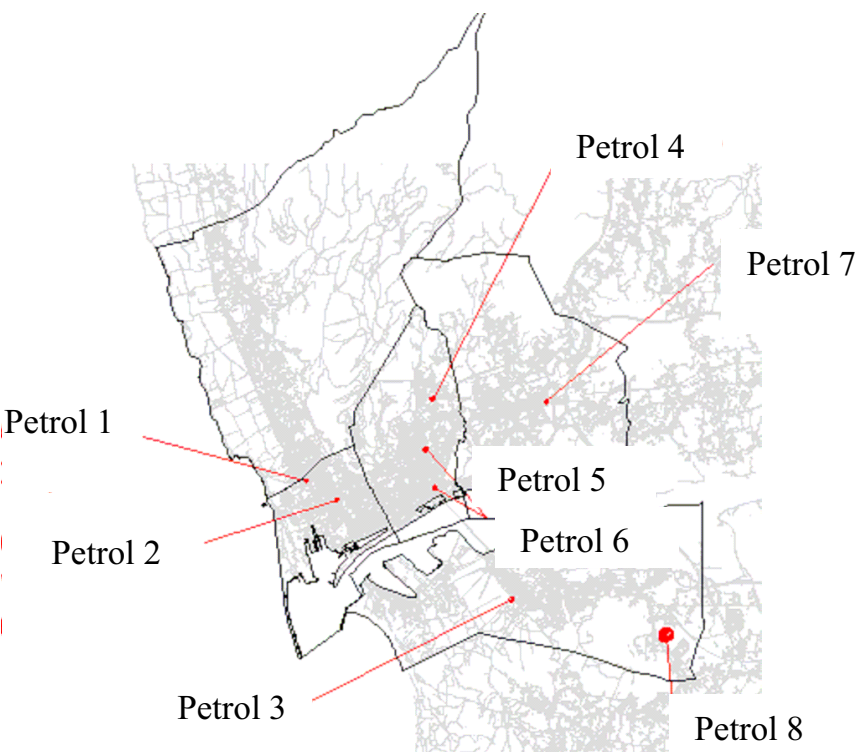

Figure 2: $\quad$ Location of the petrol stations.

Table 5: Characteristics of the petrol stations.

\begin{tabular}{|l|c|c|c|}
\hline $\begin{array}{c}\text { Petrol station } \\
\text { number }\end{array}$ & $\begin{array}{c}\text { Gasoline } \\
\text { sold [17] } \\
\text { (ton/year) }\end{array}$ & $\begin{array}{c}\text { Loading of the } \\
\text { underground } \\
\text { tank }\end{array}$ & Refuelling \\
\hline Petrol 1,2,3 & 1021,1 & $\begin{array}{c}\text { Submerged } \\
\text { filling }\end{array}$ & $\begin{array}{c}\text { Uncontrolled } \\
\text { displacement losses }\end{array}$ \\
\hline $\begin{array}{l}\text { Petrol } \\
4,5,6,7,8\end{array}$ & 1203,18 & $\begin{array}{c}\text { Submerged } \\
\text { filling }\end{array}$ & $\begin{array}{c}\text { Uncontrolled } \\
\text { displacement losses }\end{array}$ \\
\hline
\end{tabular}

Table 6: Evaporative emissions from gasoline service station operations for Viana do Castelo.

\begin{tabular}{|l|c|}
\hline Emission Source & $\begin{array}{c}\text { Emission Rate } \\
\text { (mg VOC / } 1 \text { throughput) }\end{array}$ \\
\hline $\begin{array}{l}\text { Filling underground tank: } \\
\text { Submerged filling }\end{array}$ & 880 \\
\hline $\begin{array}{l}\text { Underground tank breathing and } \\
\text { emptying }\end{array}$ & 120 \\
\hline $\begin{array}{l}\text { Vehicle refueling operations: } \\
\text { Displacement losses }\end{array}$ & 1320 \\
\hline Spillage & 80 \\
\hline
\end{tabular}


in Viana do Castelo. The ethane and methane content of gasoline evaporative emissions were considered negligible.

To estimate the amount of benzene it was assumed 3.0\% (wt.) percent benzene in gasoline and 1,2\% (wt.) fraction benzene in vapour. The global emissions of volatile organic compounds and benzene from the eight petrol stations are laid out in Table 7.

Table 7: Global emissions from petrol stations in Viana do Castelo.

\begin{tabular}{|l|c|c|}
\hline $\begin{array}{l}\text { Petrol station } \\
\text { number }\end{array}$ & $\begin{array}{c}\text { VOC } \\
(\mathrm{g} / \mathrm{h})\end{array}$ & $\begin{array}{c}\text { Benzene } \\
(\mathrm{g} / \mathrm{h})\end{array}$ \\
\hline Petrol $1,2,3$ & 195,128 & 4,280 \\
\hline $\begin{array}{l}\text { Petrol } \\
4,5,6,7,8\end{array}$ & 229,923 & 5,043 \\
\hline
\end{tabular}

\subsection{Calculation of horizontal air pollution map}

The modelling of dispersion of air pollution in built-up urban areas must integrate all the parameters which influence the dispersion, among others, the topography, the site, and meteorological conditions like the wind and the heterogeneousness of the atmosphere.

The eight petrol stations were modelled as source points located in the city of Viana do Castelo (Fig. 2). Table 7 shows the global emissions of each petrol station.

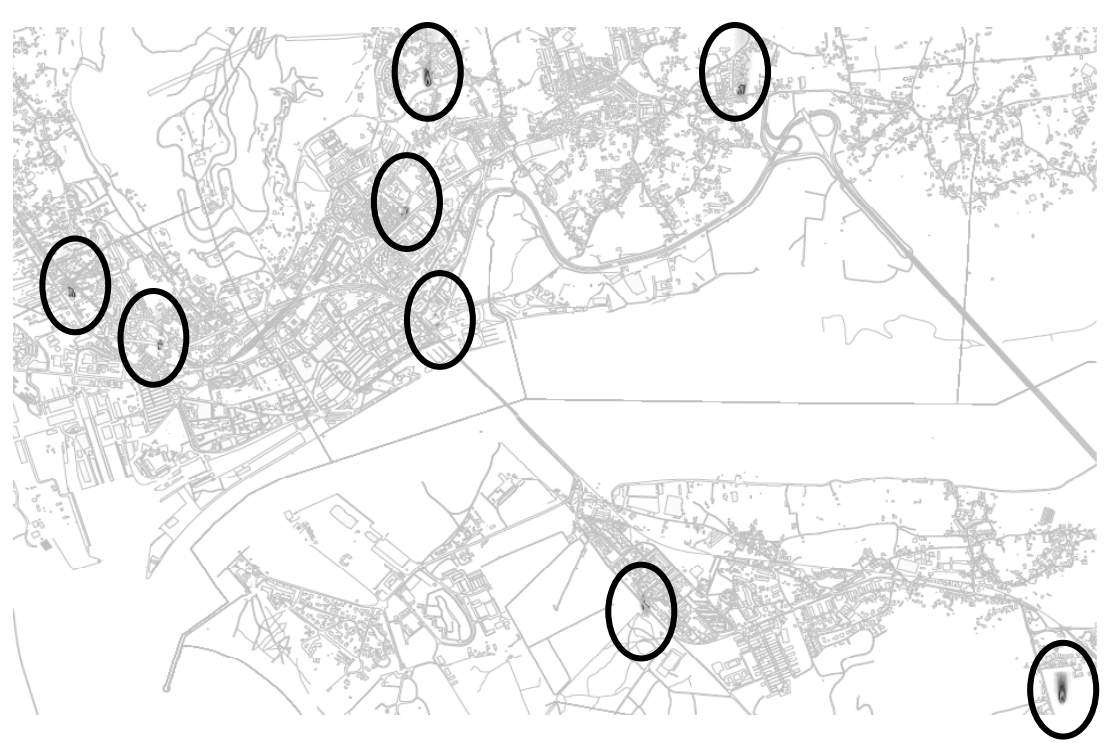

Figure 3: Benzene concentration map, $\mathrm{C}_{6} \mathrm{H}_{6}$. 


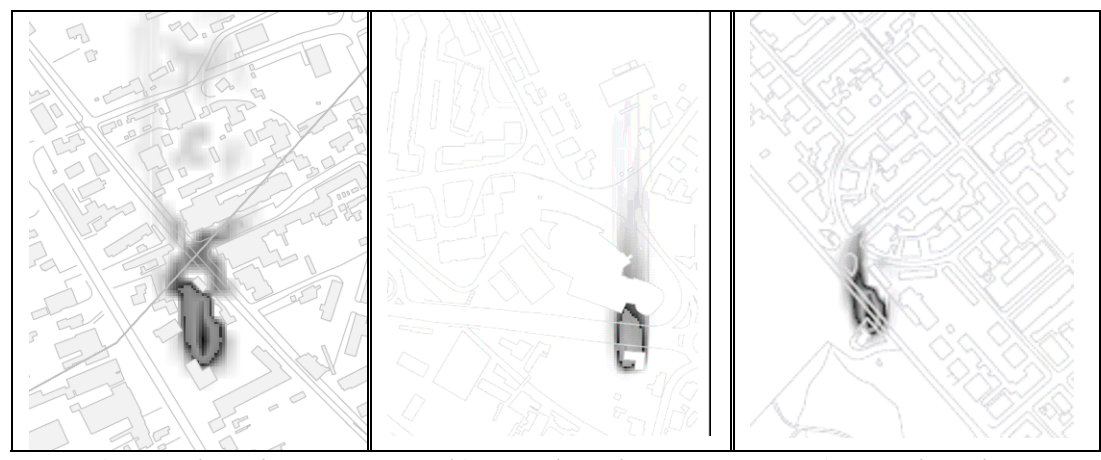
a) Petrol station 1
b) Petrol station 2
c) Petrol station 3

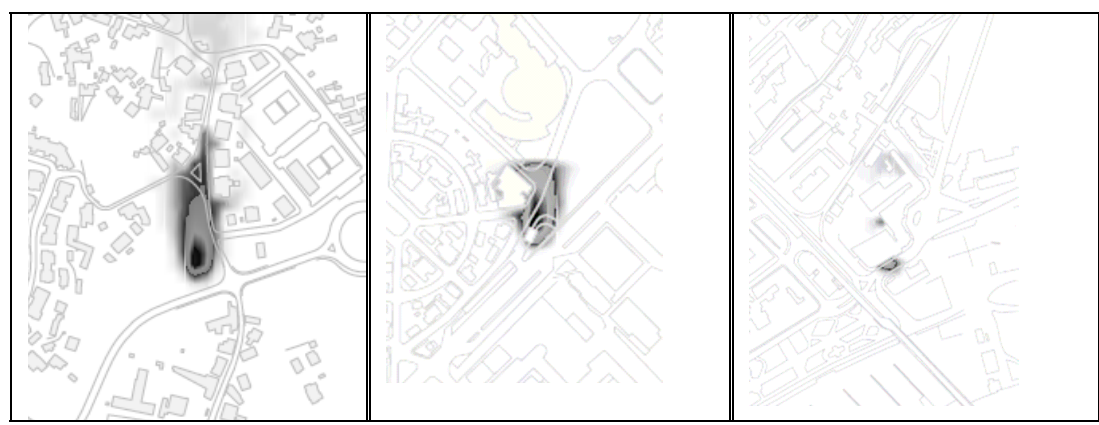

d) Petrol station 4

e) Petrol station 5

f) Petrol station 6
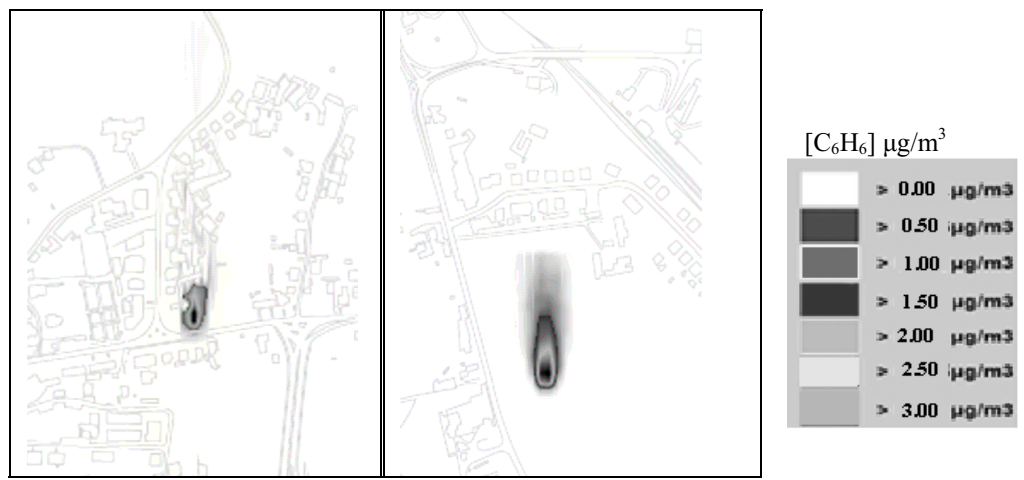

g) Petrol station 7

h) Petrol station 8

Figure 4: Horizontal maps of benzene concentration in each petrol station.

Taking the data gathered the model was used to produce the horizontal map of benzene. The following calculation parameters were adopted:

- Meteorological conditions: Data supplied by the Portuguese Institute of Meteorology (hourly)

- $\quad$ Surface roughness: $0,5 \mathrm{~m}$ 
- $\quad$ Emissions inventory: eight petrol stations (Table 7).

The concentration maps of benzene should be understood as the average situation of the atmospheric benzene due to the eight petrol stations. Figure 3 shows the long-term map of $\mathrm{C}_{6} \mathrm{H}_{6}$, representative of one year.

\section{Discussion and conclusions}

We have evaluated the atmospheric concentrations of benzene under the influence of eight emission points that represent eight petrol stations located in the city of Viana do Castelo.

We present a methodology to estimate the evaporative emissions from each petrol station and the consequent impact of such point sources on the formation of benzene concentrations in their surroundings.

The first conclusion revealed from this study is that the contribution of the petrol stations to the formation of the benzene concentrations is considerable in all the examined areas.

The results show a clear influence on the predicted benzene concentrations, depending on the activity of the petrol station, the leaks of the fuel tanks, the existence or not of obstacles in the vicinity and the meteorological conditions. As a consequence, the population living in the vicinity is exposed to an additive concentration ranging from 1 to $3 \mu \mathrm{g} / \mathrm{m}^{3}$.

Figures 3 and 4 show that the concentration of benzene is higher near the sources, i.e. in the areas adjacent to the petrol stations. Inversely, far away from those emissions sources the influence is inexistent.

Air pollution levels can be evaluated by two different means: measurements and prediction. The modelling tools can provide valuable data on benzene concentration with higher spatial and temporal resolution. Furthermore, they allow one to establish source-receptor relations and thus it evaluates the contribution of different emission sources to environmental benzene concentration and exposure levels.

Bearing in mind the several risks to the population caused by atmospheric benzene it is important to improve the evaporation recovery systems, reducing the leaks of the fuel tanks and if possible, relocating petrol stations away from the urban areas.

\section{References}

[1] Butterwick, L., Harrison, Roy. and Merritt Q. Handbook for Urban Air Improvement. Commission of the European Communities. 1991

[2] Highways Agency. Design Manual for Road and Bridges Volume 11, Section 3, Part 1 - Air Quality, UK, 2003

[3] Silva, L.T., Mendes, J.F.G. Determinação do índice de qualidade do ar numa cidade de média dimensão. Engenharia Civil. 27 , p. 63-74, 2006

[4] Spyros P. Karakitsiosa, Vasileios K. Delisa, Pavlos A. Kassomenosb, Georgios A. Pilidisa. Contribution to ambient benzene concentrations in 
the vicinity of petrol stations: Estimation of the associated health risk. Atmospheric Environment 41:2007: 1889-1902

[5] ATSDR, 1997. Toxicological profile for benzene. U.S. Department of Health and Human Services. Public Health Service Agency for Toxic Substances and Disease Registry, Atlanta, GA

[6] Guerra AI, Lerda D, Martines C. Benzene emissions from motor vehicle traffic in the urban area of Milan: hypothesis of health impact assessment. Atmospheric Environment 1995;29:3559- 3569

[7] Medinsky, M.A., Kenyon, E.M., Schlosser, P.M., 1995. Benzene: a case study in parent chemical and metabolite interactions. Toxicology 105 (23), 225-233

[8] Verma, D.K., Tombe, K., 2002. Benzene in gasoline and crude oil: occupational and environmental implications. Am. Ind. Hyg. Assoc. J. 63, 225-230

[9] Decreto-Lei n ${ }^{\circ}$ 111/2002 de 16 de Abril. Diário da República, I Série-A, Lisboa, Portugal

[10] Decreto-Lei n ${ }^{\circ} 320 / 2003$ de 20 de Dezembro. Diário da República, I Série-A, Lisboa, Portugal

[11] AP 42, Fifth Edition, Volume I Chapter 5: Petroleum Industry. July, 2008

[12] AUSTAL2000. On line: http:/www.austal2000.de

[13] UBA. On line: http://www.umweltbundesamt.de

[14] DGEG database. On line: http://www.dgge.pt 